\title{
HISTOPATHOLOGICAL AND BIOCHEMICAL STUDIES OF SOME ORGANS OF MALE ALBINO RAT FOLLOWING CHRONIC ADMINISTRATION OF BENZENE
}

\author{
EL-Sayed Nasr ${ }^{1}$ and Fawzia M. Goweder ${ }^{2}$
}

1-Zoology Depart., Fac. of Sci., Zagazig Univ., Egypt.

2-Zoology Depart., Fac. of Sci., Sabratha Univ., Libya.

\begin{abstract}
The present study was aimed to investigate the possible biochemical and histopathological effects of benzene on the liver and kidney of male albino rat. Hepatic and renal indices such as alanine and aspartate aminotransferases and alkaline phosphatase, as well as creatinine, urea and uric acid were used as markers of study. Biochemical estimation of hepatic enzymes and renal indices were significantly increased compared to control and confirmed the histopathological results which showed both hepatic and renal damage. It $b$ concluded that the ingestion of benzene-contaminated food showed a deleterious effect the liver and kidney at the employed doses and for the use period.
\end{abstract}

\section{Introduction}

Benzene is an aromatic industrial solvent and widely known environmental chemical pollutant. It can be found in varying amounts in atmosphere, water, soil, and food. It is used in manufacturing products such as rubber, lubricants, detergents, drugs, and pesticides in addation to its presence in gasoline (Synder, 2007).

Human exposure to benzene has been associated with the range of acute and long-term adverse health effects and diseases, including cancer and aplastic anaemia (WHO, 2010).Furthermore, human exposure to benzene in work environment is a universal work-related health disorders (Uzma et al., 2008; Glass et al., 2010; Khalade et al., 2010; Tunsaringkarn et al., 2013 ;NurHidayah et al., 2015 and Hetal, 2016). Moreover,the results of De Aquino et al. (2016) and Goncalves et al.(2016) suggest that petrochemical workers and laboratory technicians who directly exposed to benzene and other organic 
solvents have increased levels of chromosomal damageand enhance the carcinogenesis risk.

Benzene is the most common chemical known to cause liver injury . Contact with benzene has been related to many different hazardes in both animals and human (Turteltaub and Mani, 2003). Benzene also induces oxidative damage and apoptosis in the nervous system (Manno, 2013). A large section of population is occupationally exposed to benzene through work environment (Ragia et al., 2014). Moreover, prenatal exposure to benzene could produce long-lasting neurotoxicity.Human contact to benzene can occur not only through breathing and dermal absorption, but also through eating food and drinking water (Lo Pumo et al., 2006).

Organic solvents especially benzene may express their toxicity by the way of reactive oxygen species (ROS) that was found to induce cell damage (AbdEllah et al., 2007). Majority of benzene metabolism occurs in liver by cytochrome $\mathrm{P} 450$ and then in bone marrow (Uzma et al., 2008).

The liver plays a critical role in the metabolism, digestion, detoxification and elimination of almost all forgin substances from the body. It is the site where the metabolism and subsequent elimination of endogenous and exogenous compounds takes place.Liver and kidney are important organs for metabolism, detoxification, storage and excretion of xenobiotics and their metabolites, and are especially vulnerable to damage (Bunout, 1999 and Thurman et al., 1999). Although the effects of benzene on the biochemical and physiological aspects have been early,the pathological changes received less attention.However,animal data about benzene exposure regarding toxicity effect remains few, so this article aims to discuss the histopathological hazards of benzene on rat's liver and kidney.

\section{Material and Methods}

\section{Animals and housing conditions}

Thirty Swiss albino male rat of average body weight about $(150 \pm 5 \mathrm{gm})$ and about three month age were obtained from Animal Division, Faculty of Vet. Zagazig University.

\section{Design of the experiment:}

The animals were randomly selected and kept in plastic cages with wood-cobe bedding (10 rat/cage) and fed with commercial pelleted feed. After a week of acclimation, the rats were divided into three groups. The first group was fed benzene- contaminated food of a dose $0.5 \mathrm{ml}$ benzene/animal/day after day for eight weeks, the second group received double the preceding dose 
(1 $\mathrm{ml} /$ animal/ day after day for eight weeks). The third group was served as a control. All groups were maintained with 12-h: 12-h photo-period cycle with available supply of distilled water.

\section{Collection of the samples:}

At the end of the eight weeks, rats were anaesthetized by using cotton wool soaked in chloroform. When they became unconscious, their neck area was cleared of fur and skin to expose the jugular veins which were then cut sharply with sterile scalpel blade and the rats were held head downwards to bleed into clean dry corked test tubes. The collected blood is allowed to clot and left for 10 minutes at room temperature for serum formation. The serum was collected after centrifugation at $3000 \mathrm{rpm}$ for 5 minutes, kept frozen and used for the determination of liver and kidney function analyses within 12hours of collection. Aspartate transaminase (AST), alanine transaminase (ALT) were estimated using method of Bergmeyer et al. (1979) also, alkaline phosphatase (ALP) is measured according to Tietz et al. (1983). Kidney indices as creatinine, urea and uric acid were estimated using the diacetyl monoxime oxidase method by an automated machines (Roche Diagnostic, Germany). All obtained data are expressed as mean $\pm \mathrm{SD}$ and mathematically analyzed using Student's T-test.

For histopathological purposes, rats were quickly dissected, and the left lobe of liver and left kidney were taken and fixed in $10 \%$ buffered formalin solution, passed through ascending series of ethanol baths, cleared in xylene and embedded in paraffin. Tissues were sectioned at $4 \mu \mathrm{m}$ and stained with Hematoxylin and Eosin (H\&E). The sections were examined and photographed by light microscope.

\section{Results}

The results of this study are presented in tables $(1 \& 2)$ as well as figures (A and B). Table (1) shows that the activities of the hepatic enzymes (ALT, AST and ALP) were significant increase $(\mathrm{P}>0.05)$ in benzene-treated group when compared with control values. Results in table (2) also revealed that administration of rats with benzene caused significant elevation $(\mathrm{P}<0.05)$ in the levels of creatinine, urea and uric acid compared with control. 
Table (1): Serum levels of hepatic enzymes in benzene treated rats.

\begin{tabular}{lccc}
\hline & AST & ALT & ALP \\
\hline Control & $150 \pm 50$ & $48 \pm 5$ & $160 \pm 30$ \\
First group & $230 \pm 20$ & $55 \pm 6$ & $190 \pm 40$ \\
Second group & $233 \pm 15$ & $59 \pm 5$ & $191 \pm 45$ \\
\hline
\end{tabular}

\section{Liver}

Light microscopic examination of the paraffin sections of liver in the control group revealed normal architecture of the hepatic tissues. Hepatocytes were arranged in radial cords around the central vein and separated by blood sinusoids (Figure A, 1). Nonetheless, liver of benzene-contaminated fed groups showed dilation of central vein, enlargement of sinusoids, in addition of focal necrosis and pyknosis, cloudy swelling of hepatocytes. Widening of sinusoids with activation of kupffer cells were also seen (Figure A, 2). Furthermore, with the increase of dose of administration, there is a focal infiltration of lymphocytes in the liver parenchyma with vacoulation of hepatocytes accompanied with sever dilation of the central vein (Figure A, 3). The liver of rats treated with benzene for eight weeks revealed multiple areas of focal necrosis characterized by pyknosis or disappearance of nuclei of hepatic cells and loss of normal pattern of hepatic cords (Figure A, 3). There are no wide differences between the different treated groups.

Table 2: Serum levels of urea, creatinine and uric acid in benzene treated rats.

\begin{tabular}{lccc}
\hline & Creatinine $\mu \mathrm{g} / \mathrm{dl}$ & Urea $\mu \mathrm{g} / \mathrm{dl}$ & uric acid $\mu \mathrm{g} / \mathrm{dl}$ \\
\hline Control & $22 \pm 0.3$ & $40 \pm 0.1$ & $220 \pm 20$ \\
First group & $31 \pm 0.2$ & $41 \pm 0.1$ & $300 \pm 10$ \\
Second group & $30 \pm 0.1$ & $42 \pm 0.2$ & $420 \pm 30$ \\
\hline
\end{tabular}

\section{Kidney}

The histological sections of kidney showed normal structural appearance in control group (Fig. B, 1), whereas in benzene-contaminated fed groups kidney sections showed atrophy of glomeruli accompanied with marked dilation of Bowman's space (Fig. B, 2). Focal areas of increased glomerular cellularity in the form of mesangial expansion and diffuse thickening of the glomerular capillary walls with multifocal vascular congestion were also observed in kidney of treated animals (Fig. B, 2). Degeneration of brush border of 
convoluted tubules that appeared with eosinophilic casts in their lumen was observed in the highly benzene-dose administered rats (Fig. B, 3).
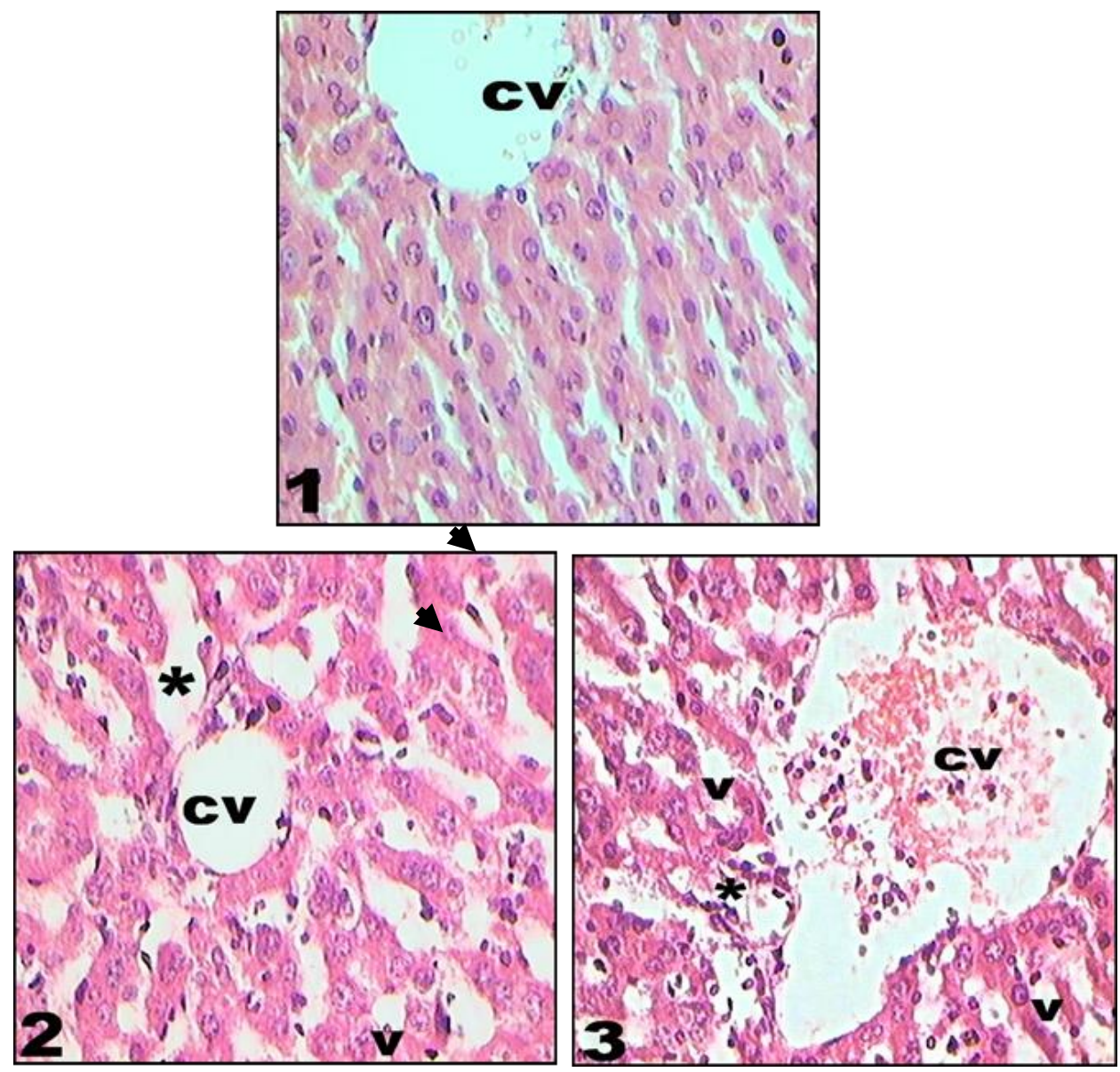

Figure (A)1: showing normal histological profile of a liver section with central vein (cv) and radialy arranged hepatic cord .(2): Low dose benzene treatment with areas of focal necrosis \& pyknosis (v), and sinusoidal dilation (*). (3): High dose bezene treatement liver losing normal architecture with severe dilation of central vein (cv), marked lymphocytic infiltration (*), enlargement of sinusoids (arrows), cloudy swelling of hepatocytes (v). X 400. 

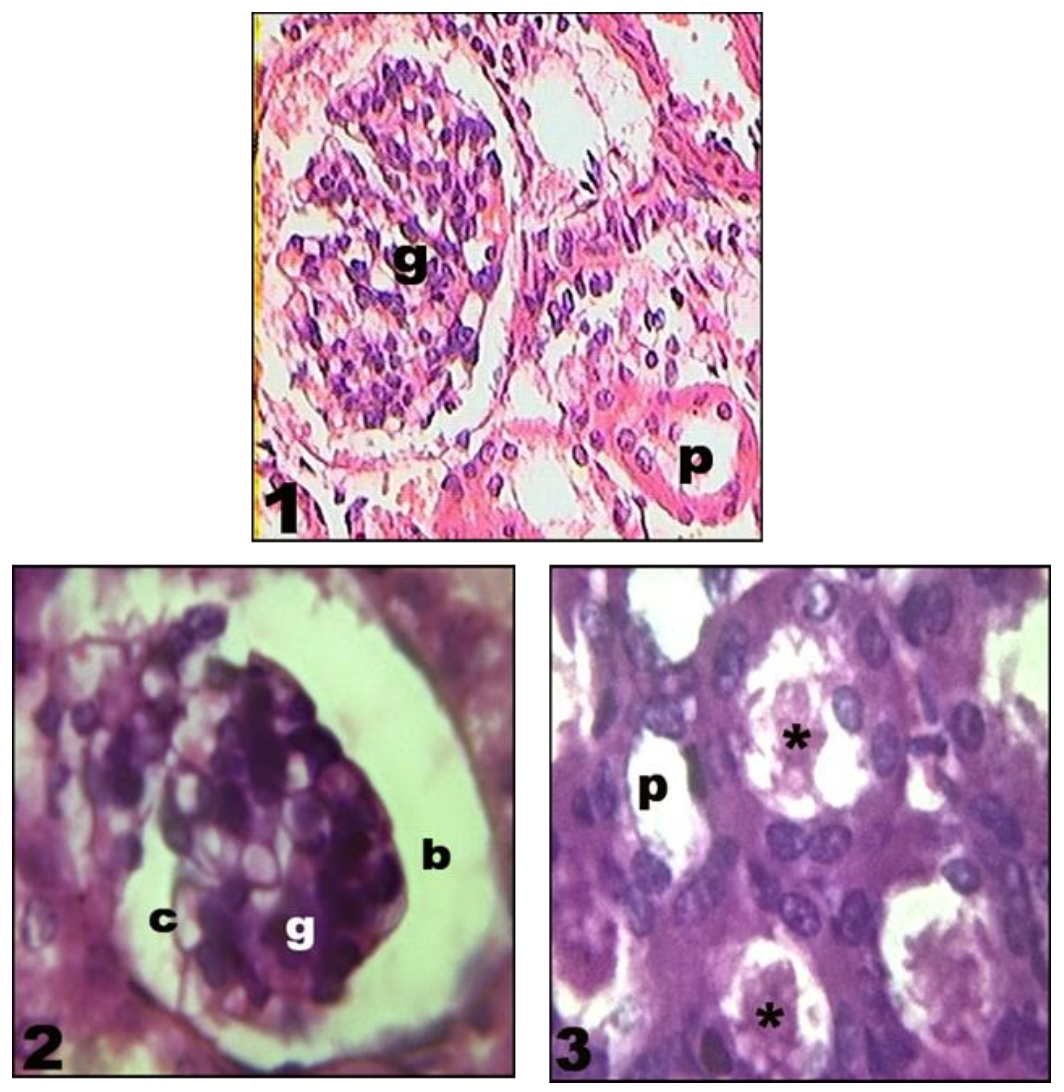

Figure B, 1: section of normal rat kidney showing the glomerulus (g)with its Bowmann`s capsule,the proximal convoluted tubule (p).2: kidney of benzene treated specimen showing the shrinkage of glomerulus (g) with difused thickining capillaries (C), mesangial expansion (arrow) and widening of Bowmann`s space (b).3: a set of proximal convoluted tubules (p) losing brush borders and have amorphus eosinphilic casts in the lumen of some of them(*). X 400 .

\section{Discussion}

Benzene is an important component of petrol. It is a widely distributed environmental contaminant and has been associated with increased incidence of blood disorders (Carletti and Romano, 2002).

Liver is a rich source of the enzymes responsible for biotransformation of substances such as drug and toxins which are converted to hydrophilic highly reactive compounds and damaging effects to cellular biomolecules (Hodgson, 2004). Moreover, the liver and the kidney are of the organs normally used to assess the toxicity of exogenous compounds (Dafour et al., 2006). The effects of acute and chronic exposure of animals to crude oil and its refined products 
could be studied by evaluating the biochemical changes in various organs especially the liver. Since, aminotransferases (ALT, AST) and alkaline phosphatase (ALP) levels are helpful screening tool to detect injury of hepatocyte. The significant increase of ALT, AST and ALP in the serum of rats in the present study may be due to severe hepatic injury (necrosis, vacuolar degeneration). Moreover, blood enzymes have been considered as indicators of the hepatic dysfunction and damage of the tissue (Khan et al., 2001).

Currently, the reason for the elevation of the enzyme activities occurring in serum in this study may be due to the effect of benzene on the cellular organelles in the tissues. The influence on cell organelles will indirectly influence the enzyme activities. The increase in the enzymes activities in serum of benzene-treated specimens is mainly due to the leakage of these enzymes from the liver cytosol into the blood stream. In other word enzymes activities increase in serum when cellular degeneration or destruction occurs in liver. Activity of AST increases significantly in such cases and escapes into the plasma from the injured hepatic cells. In addition, ALT level is of value, which also indicates the existence of liver disorder, as this enzyme is present in large quantities in the liver. Rahman et al. (2000) suggested that the increase in the enzymes activities in plasma might be due to the increased permeability of plasma membrane or cellular necrosis, and this showed the stress condition of the treated animals.

On the contrary, the decline in serum activity of ALT and AST of rats may indicate recovery of poor prognosis in fulminant hepatic failure (Friedman $\boldsymbol{e} t$ al., 2003). Other investigators also reported elevated liver enzymes among animals exposed to benzene or petroleum products and organic solvents (Uzma et al., 2008; Mohammadi et al., 2010; Chang et al., 2013; Mark et al., 2014). The increased serum levels of these enzymes could be due to the overproduction or release of enzymes from the liver cells in response to stimuli of hepatocellular injury or cell death (Mark et al., 2014). Furthermore, the plasma membrane and lysosomes are specific benzene targets as evident by alterations in their specific biomarkers. On the contrary, Sharma et al. (1995) stated that the increase in the enzyme activity may not be unconnected with a disturbance in the transport of metabolites.

Benzene may directly affect organelles at the cellular level in various tissues, which will indirectly influence enzyme activities as stated by Patrick $\boldsymbol{e t} \boldsymbol{a l}$. (2011). While, Lin et al. (2000) attributed the increase of these investigated enzymes are found after cellular damage. The findings of the present study 
indicate that benzene-contaminated food induces significant alterations in hepatic functions. The higher levels of liver enzymes in serum were supported by histopathological alteration of hepatic tissue. Necrosis was observed in treated tissue of rat liver which is one of the possible causes of increased enzyme activity. Benzene and its metabolic molecules lead to alteration in the architecture of liver.

The kidney though an organ that maintains homeostatic mechanisms of the body therefore blood level of creatinine, urea and uric acid are used to assess the degree of renal damage (Iyanda, 2014).

The results of this study showed an increase in serum levels of creatinine, urea and uric acid in rats fed benzene contaminated diets relative to the control. These results indicate that exposure to benzene may cause impairment of the renal function. The impairment of the renal function implies that benzene derivatives may contains more nephrotoxic constituents. This collaborates with the results of previous studies of Ovuru et al., (2004) and Achuba and Ogwumu (2014) on the toxicity of crude petroleum and its refined products. The increased levels of urea and creatinine observed in this study indicate a deficiency in the kidney's capacity to excrete these waste products. This could be due to a decrease in glomerular filtration rate as stated by Ovuru $\boldsymbol{e t}$ al., 2004.

Feeding benzene-contaminated diets for a long period resulted in significant increase in serum creatinine and blood urea indicating benzene induced nephrotoxicity. These results agree with that of Khan and Yusuf (2009). The significant elevation in creatinine may be an indication of compromise of the renal function. Benzene may interfere with the metabolism of creatinine leading to its increase in the serum or it is due to partial loss of functional capacity of tubular excretion (Segasothy et al.,1994).

In conclusion, the results of this work suggest that repeated feeding with benzene-contaminated food may elicit hepatotoxicity as well as renal lesions, thereby impairing their normal functions. Therefore, petrochemical workers and laboratory technicians should have regular medical check-up to ascertain their health condition.

\section{References}

AbdEllah, M.; Okada, K. and Yasuda, J. (2007): Oxidative stress and bovine liver diseases: Role of glutathione peroxidase and glucose 6 phosphate dehydrogenase. J. Vet. Res., 54: 163-173.2. 
Achuba, F.I. and Ogwumu, M.D. (2014): Effect of palm oil and beef liver on diesel-induced haematotoxicity in wistar albino rats. Biokemistri26: $120-123$

Bergmeyer, H.U.; Scheibe, P. and Wahlefeld, A.W. (1979): Methods for aspartate and alanine amino transferase. Clin. Chem., 125: 1487

Bunout, D. (1999): Nutritional and metabolic effects of alcoholism. Their relationship with alcoholic liver disease. Nutrition 7-8: 583-589.

Carletti, R. and Romano, D. (2002): Assessing health risk from benzene pollution in an urban area," Environmental Monitoring andAssessment, vol. 80, no. 2: 135-148.

Chang, W.J.; Joe, K.T.; Park, H.Y.; Jeong, J.D. and Lee, D.H. (2013): The relationship of liver function tests to mixed exposure to lead and organic solvents. Ann. Occup. Environ. Med., 25: 5.

Dafour, D.R.; Lott, J.A. and Nolte, F.S. (2006): Diagnosis and monitoring of hepatic injury. Recommendations for use of laboratory tests in screening, diagnosis and monitoring. Clin. Chem.; 46: 2050-2068.

De Aquino, T.; Fernanda, F. Z.; JOEL, H. E.; Daniel, P., and Alexandre R. (2016): DNA damage and cytotoxicity in pathology laboratory technicians exposed to organic solvents. 5:1-10. An. Acad. Bras. Cienc.: $1-10$.

Friedman,S.F.; Martin, P. and Manoz, J.S. (2003): Laboratory evaluation of the patient with liver disease. In: Histopathology. A text book of liver disease. Philadelphia, Sounders Publication.1, 661-709

Glass, D.C.; Armstrong, T.W.; Pearlman, E.D.; Verma, D.K.; Schnatter, A.R. and Rushton, L. (2010): Ensuring comparability of benzene exposure estimates across three nested case-control studies in the petroleum industry in support of a pooled epidemiological analysis. Chem. Biol. Interact., 184: 101-111.

Goncalves, R.O.; de Almeida, N.M. and Rego, M. A. V. (2016): Association between occupational exposure to benzene and chromosomal alterations in lymphocytes of Brazilian petrochemical workers removed from exposure. Environ Monit. Assess, 188: 334.

Hetal, R. (2016): Evaluation of benzene induced histopathological alteration in rat. International Journal of Advanced Research, 4 (6): 563-567.

Hodgson, E. (2004): A textbook of modern toxicology. 3rd edition. John Wiley and Sons, Inc., New Jersey: 203-211. 
Iyanda, A.A. (2014): Hepatotoxic and nephrotoxic effects of kerosene on female wistar rats: a comparison of two routes of exposure. J. Phys. Pharm. Adv., 4(1): 303-309.

Khalade, A.; Jaakkola, M.S.; Pukkala, E. and Jaakkola, J.J. (2010): Exposure to benzene at work and the risk of leukemia: A systematic review and meta-analysis. Environ. Hlth., 9: 31-38

Khan, S. and Yusuf, A. (2009): Effect of benzene on the enzymes of carbohydrate metabolism, brush border membrane (BBM) and oxidative stress in kidney and other rat tissues. Biology and Medicine, 1 (2): 2841.

Khan, I.A.; Reddy, B.V.; Mahboob, M.; Rahman, M.F., and Jamil, K. (2001): Effect of phosphorothionate on the reproductive system of male rats. J. Environ. Sci., and Health, Part B, 36: 445-456.

Lin, S.C.; Chung, T.C.; Ueng, T.H.; Linn, Y.H.; Hsu, S.H.; Chiang, C.L. and Lin, A. (2000): The hepato-protective effects of Solanum alatammoech on acetaminophen-Induced hepatotoxicity in mice. Am. J. Clin. Med., 28: 105-114.

Lo Pumo, R.; Bellia, M.; Nicosia, A.; Micale, V. and Drago, F. (2006): Long-lasting neurotoxicity of prenatal benzene acute exposure in rats. Toxicology; 223: 227-34.

Manno, M. (2013): Update on benzene: from industrial toxicant to environmental carcinogen. G. Ital. Med. Lav. Ergon.; 35: 247-50. Italian.

Mark, A.; D'Andrea, G. and Kesava, R. (2014): Hematological and hepatic alterations innonsmokingresidents exposed to benzene following a flaring incident at the British petroleum plant in Texas City. Environ. Health., 13: 115-117.

Mohammadi, S.; Mehrparvar, A.; Labbafinejad, Y. and Attarchi, M.S. (2010): The effect of exposure to a mixture of organic solvents on liver enzymes in an auto manufacturing plant. J. Public Health., 18: 553-557.

Nur-Hidayah, H.; NurHayatul, A.M.; Lian, H.H., Rasyidah, T.I.; Kaswandi, M.A. and Noah, M.R. (2015): Effect of inhaled benzene on mice's peripheral blood: Erythrocyte morphology and count analysis, hematocrit \& hemoglobin level and erythrocyte indices. Inter. Proc. Chem., Biol. and Environ. Engin., 90: 114-120.

Ovuru, S.S.; Berepubo, N.A. and Nodu, M.B. (2004): Biochemical blood parameters in semi-adult rabbits experimentally fed crude oil contaminated diets. African J. of Biotechnol., 3: 343-345. 
Patrick, K.F.; Onyemaenu, C.C.; Egwu, M.O. and Ayalogu, E.O. (2011): Hepatic and nephrotoxic effects of kerosene and petrol- contaminated diets in wistar albino rats. Res. J. Environ. Toxicol., 5(1): 49-57.

Ragia, M.; Hegazy, H.F. and Kame, M. (2014): Oxidant Hepatic and /or Haem. Injury on Fuel-Station Workers Exposed to Benzene Vapor, Possible Protection of Antioxidants. AJMS., 4: 35-46.21.

Rahman, M.F.; Siddiqui, M.K., and Jamil, K. (2000): Acid and alkaline phosphatase activities in a novel phosphorothionate (RPR-11) treated male and female rats; evidence of dose and time-dependent response. Drug and Chemical Toxicology, 23: 497-509.

Segasothy, M.; Swaminathau, M. and Kong, N.C. (1994): Acute renal failure infalciparum malaria. Med. J. Malaysia. 49: 412-415.

Sharma, A.; Mathur, R., and Skukla, S. (1995): Hepato-protective action of a proprietary herbal preparation against carbon tetrachloride intoxication. Indian Drugs 32: 120-124.

Snyder, R. (2007): Benzene's toxicity: a consolidated short review of human and animal studies by HA Khan. Hum Exp. Toxicol.; 26:687-96.

Tietz, N.W.; Rinker, A.D. and Shaw, L.M., (1983): method for alkaline phosphatase (orthophosphoric-monoester phosphor hydrolase, alkaline optimum). J. Clin. Chem. Clin. Biochem., 21: 731-748.

Thurman, R.G.; Bradford, B.U.; Iimuro, Y.; Frankenberg, M.V.; Knecht, K.T.; Connor, H.D.; Adachi, Y.; Wall, C.; Arteel, G.E.; Raieigh, J.A.; Forman, D.T. and Mason, R.P. (1999): Mechanisms of ethanolinduced hepatotoxicity: studies in rats. Frontiers in Bioscience 4: 42-46.

Tunsaringkarn, T.; Soogarun, S. and Palasuwan, A. (2013): Occupational exposure to benzene and changes in hematological parameters and urinary trans, trans-muconic acid. Inter. J. Occupt. Environ. Med., 4(1): 45-49.

Turteltaub, K.W. and Mani, C. (2003): Benzene metabolism in rodents at doses relevant to human exposure from urban air. Res Rep Health Eff Inst; 113: 1-35.

Uzma, N.; Kumar, B.; Salar, K.; Madhuri, A. and Reddy, V. (2008): In vitro and in vivo evaluation of toxic effect of benzene on lymphocytes and hepatocytes. Inter. J. Toxicol, 6: 2.

WHO (2010): Preventing disease through healthy environments. Exposure to benzene: A major public health concern. 
دراسات هستوباثولوجيه وبيوكيميائية على بعض أعضاء الفئران البيضاء بعد التعاطي المتكررللبنزين

\section{السيد نصر 1ـ فوزيه قويدر2}

1 1-قسم علم الحيوان- كلية العلوم- جامعة الزقازيق- مصر 2-قسم علم الحيوان -كلية العلوم -جامعة صبراته ليبيا

أستهفت الدراسة الحاليه تقييم احتمال التأثثرات الناجمة عن تناول الأغذية الملوثة بالبنزين على كبد كلى ذكور الفئر ان البيضاء. استخدمت لهذه الدر اسة ثلاث مجموعات من الفئران (10/كل مجموعه). جُر عت المجموعة الأولى غذائاً ملوثاً بالبنزين بتركيز 0.5مل/حيوان ، بينما تناولت المجموعة الثانية غذاءاً ملوثاً بالبنزين بمعدل 1مل/حيوان وثُركت المجموعة الثالثة كمجموعة ضابطة بدون تلويث غذائها بالبنزين .استمرت التغذية يوما بعد يوم لمدة ثمانية اسابيع.في نهاية التجربة ذبحت الفئران وتم قياس مستوى الإنزيمات الكبدية مثل ألانين أمينو ترانسفيريزوأسبارتات ترانسفيريزوالفوسفاتيز القلوي، وكذلك الكرياتينين و اليوريا وحمض اليوريك في بلازما الدم. واستخدمت المؤشرات الحيوية كمقياس لمدى التأثر. وقد أثنتت الدراسة أنّ التقديرات البيوكيميائية لهذه المؤشرات في زيادة كبيرة مقارنة بالمجموعة الضابطة. جاءت النتائج النسيجيه والباثولوجيه لكل من الكبد والكلى مؤكدة

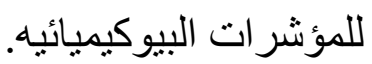

ويمكننا الاستنتاج أن تناول الأغذية الملوثة بالبنزين يؤدي الى خللٍ في وظائف كلا من الكبد والكُلبه فضلاً عن أضر ارِ هستولوجيه بالكبد و الكليه تتاسبت طردياً مع مقدار الجر عه وفترة التعرض. 